\title{
A pesquisa educacional entre conhecimentos, políticas e práticas: especificidades e desafios de uma área de saber ${ }^{*}$
}

\author{
Bernard Charlot
}

Universidade Paris 8, França e Organização da Nações Unidas para a Educação, a Ciência e a Cultura (UNESCO)-Brasil

\section{Introdução}

Quem atua no ensino de ciências da educação, na França, ou em uma estrutura de pós-graduação em educação, no Brasil, tem um problema de identidade profissional. Quando me perguntam sobre o que ensino, sobre o tema de minhas pesquisas, e respondo "ciências da educação", ou me perguntam do que se trata (reação que predomina na França), ou acreditam que trabalho com formação de professores (reação que predomina no Brasil). Em suma, sou especialista de algo impreciso, sem fronteiras claras, e difícil de identificar. O que, evidentemente, não é muito agradável do ponto de vista narcísico.

Mas não sou o único nessa situação. Se pensarmos no assunto, a ANPEd não é mais clara do que eu... Associação Nacional de Pós-Graduação e Pesquisa em Educação. O que significa "em educação"?

* Conferência de abertura da $28^{\mathrm{a}}$ Reunião Anual da ANPEd, realizada em Caxambu (MG), de 16 a 19 outubro de 2005. Traduzida por Anna Carolina da Matta Machado.
Será que guarda o mesmo sentido que "em sociologia”, "em psicologia", "em filosofia", "em física"? Nesse caso, "em educação" remete a uma disciplina que chamaríamos educação. Ou será que significa "sobre educação", "acerca da educação", "a respeito da educação"? Nesse caso, "educação" remete-nos a um conjunto de situações, de práticas, de políticas ligadas à educação no sentido amplo do termo. Assim, a ANPEd é uma associação que reúne pesquisadores de diferentes disciplinas, interessados na questão da educação. A questão-chave, portanto, é: são vocês, somos nós, pesquisadores debruçados em estudos em educação ou sobre educação?

Podemos colocar essa questão de outras duas formas, ligadas ao próprio título desta conferência.

Existe uma pesquisa educacional, específica, original? Ou esse é o nome que damos a um conjunto de pesquisas de cunho psicológico, sociológico, pedagógico, didático, que tratam da educação ou da formação?

Existe uma área de saber chamada educação (ou ciências da educação, o nome pouco importa, o importante é que ela seja uma área de saber), ou será 
que a educação é uma área de práticas e de políticas sobre as quais diferentes ciências humanas e sociais produzem conhecimento?

A maneira como respondemos a essa questão (porque, de fato, ela é a mesma, mas em três formas) é, evidentemente, essencial para definir a pesquisa em educação ou sobre educação, sua especificidade, seus desafios, os elos entre os conhecimentos, práticas e políticas. Essa questão, portanto, será o eixo principal da minha conferência.

Eu a abordarei por meio de três frentes sucessivas. Em primeiro lugar, como os próprios pesquisadores, na França e, acredito, no Brasil, respondem a essa questão? Em segundo lugar, quais são, atualmente, os diferentes tipos de discursos produzidos sobre a educação, e quais são suas características? Em terceiro lugar, qual poderia ser a singularidade de uma disciplina original, que permanece em construção, denominada ciências da educação, ou educação, e o que podemos fazer, sobretudo quando temos a força institucional e científica da ANPEd, para permitir o avanço e valorizar a especificidade e a originalidade da pesquisa em educação?

É claro que, abordando três temas dessa amplitude, não tenho a pretensão de esgotar o assunto.

\section{A especificidade da educação como campo de conhecimento e de pesquisa: os pontos de vista dos professores universitários e pesquisadores}

Os universitários que atuam nos departamentos, institutos, faculdades de ciências da educação, ou em cursos de pós-graduação em educação, não estão de acordo sobre a existência de uma disciplina específica chamada ciências da educação ou educação. $\mathrm{Na}$ minha opinião, há três posições possíveis:

1. Os departamentos, faculdades etc. são apenas espaços institucionais, nos quais colaboram especialistas de diferentes áreas. São locais onde encontramos sociólogos, psicólogos, matemáticos ou geógrafos que se interessam pelo ensino, pedagogos especializados em pedagogia (que não sabemos bem precisar o que é, mas que parece estar ligada a questões práticas). Essas pessoas trabalham juntas, nos mesmos ambientes - os departamentos de educação -, pesquisam nas mesmas estruturas da pós-graduação, mas isso não quer dizer que existe uma disciplina, um campo de pesquisa específico chamado educação ou ciências da educação. As ciências da educação possuem uma realidade institucional, administrativa, organizacional, mas não têm existência epistemológica específica. Faço pesquisa em sociologia da educação, meu colega a faz em psicologia da educação, um outro em didática do ensino da matemática, pertencemos a um departamento de educação, à mesma pós-graduação, mas não existe pesquisa educacional, e sim uma pesquisa sociológica, psicológica, didática etc. sobre temas ligados à educação. Por conseguinte, o problema da especificidade da disciplina educação está resoluto, por não ser mais colocado.

2. A idéia de uma cultura comum. Um colega, Michel Bataille, explicou-me um dia, de modo interessante, qual era, na sua opinião, a diferença entre ser psicólogo educacional em um departamento de psicologia e em um departamento de ciências da educação. Quando trabalhamos em um departamento de psicologia, interessamo-nos prioritariamente pelo que é publicado na área de psicologia, o que inclui outros temas além da educação. Ao passo que, quando somos psicólogos educacionais em um departamento de ciências da educação, interessamo-nos sobretudo por aquilo que se publica sobre educação, estando aí incluídas áreas diferentes da psicologia. Assim, em um departamento, em uma pós-graduação, e, além disso, nas "ciências da educação", constrói-se pouco a pouco uma cultura comum, fortemente inter ou transdisciplinar.

Essa cultura comum permite que as questões sejam colocadas de outro modo, produz uma especificidade das pesquisas desenvolvidas nas faculdades de educação. Isso me parece poder estabelecer o consenso entre aqueles que dão importância ao fato de trabalhar no mesmo campo, "a educação". Quer continuemos a nos definir por uma disciplina de origem (sociologia, matemática etc.), quer sonhemos com a 
construção de uma disciplina específica denominada educação, podemos concordar com essa idéia de cultura comum e com o fato de que ela introduz uma certa especificidade nas pesquisas feitas na pós-graduação em educação. Com a condição, é claro, de interessarmo-nos pelo que fazem nossos colegas, de ler o que eles produzem, de promover debates com eles, de ter projetos comuns. Quem aceita essa idéia de cultura comum já introduz uma especificidade no campo da pesquisa educacional.

Podemos estender essa idéia, como fiz há dez anos, em meu livro sobre ciências da educação (Charlot, 1995). Essa cultura comum não se define somente pela atenção dedicada às pesquisas de outras disciplinas sobre a educação, mas também por uma certa relação que se estabelece entre as práticas e as políticas no campo da educação.

Quem é sociólogo de educação se define antes de tudo como sociólogo, se interessa pela contribuição que a educação pode dar à estruturação do campo social. O que lhe interessa é a construção do social e, se ele trabalha sobre a educação, é para melhor compreender essa construção. No fundo, a questão mesma da educação não o interessa de fato, o que chama a sua atenção são os seus efeitos sociais. Bourdieu é um autor típico desse caso: o que o interessa não é a educação, mas a reprodução social.

Ao contrário, o pesquisador que se defina "de educação", qualquer que seja sua origem acadêmica, se interessa fundamentalmente pela questão da educação; é isso que o leva a dar importância, de um lado, à própria educação, naquilo que ela tem de específico, e, de outro lado, aos efeitos da pesquisa sobre a educação. Como consequiência, ele não poderá mais se desinteressar, se desligar das questões relativas aos fins (em que se incluem as questões políticas) e das questões relacionadas à prática. Os conhecimentos que ele produz são levados em consideração, interpelados, negados, ignorados pelos políticos e pelos práticos, e o pesquisador em educação não pode negligenciar a importância disso. É comum que o pesquisador, ao chegar aos resultados de uma pesquisa, se preocupe com a questão: "o que eles farão com esses resul- tados?”. Sem falar daquele que é tão prudente que já determina os resultados antes mesmo de começar sua "pesquisa"...

O que é específico da educação como área de saber é o fato de ela ser uma área na qual circulam, ao mesmo tempo, conhecimentos (por vezes de origens diversas), práticas e políticas. Delimita-se assim uma primeira definição da disciplina educação ou ciências da educação: é um campo de saber fundamentalmente mestiço, em que se cruzam, se interpelam e, por vezes, se fecundam, de um lado, conhecimentos, conceitos e métodos originários de campos disciplinares múltiplos, e, de outro lado, saberes, práticas, fins éticos e políticos. O que define a especificidade da disciplina é essa mestiçagem, essa circulação.

Portanto, por definição, é uma disciplina epistemologicamente fraca: mal definida, de fronteiras tênues, de conceitos fluidos. Ela não tem e jamais terá a aparente pureza e clareza da sociologia ou da psicologia. Quem desenvolve pesquisas na área da educação é sempre um pouco suspeito, e com freqüência obrigado a justificar-se, com relação a questões como: "O que é exatamente esta pesquisa? É de psicologia, de sociologia, é o quê?". Mas, também por definição, é uma disciplina capaz de afrontar a complexidade e as contradições características da contemporaneidade. Quem deseja estudar um fenômeno complexo não pode ter um discurso simples, unidimensional.

Existem, aliás, outras disciplinas mestiças, nas quais se articulam conhecimentos oriundos de diversos campos, práticas, políticas: as ciências políticas, as ciências de administração, o urbanismo - e também a medicina, mas não percebemos isso tão claramente. São disciplinas que possibilitam a inserção da inteligibilidade e da racionalidade em campos prático-éticos complexos e, por atuarem nesses campos, que correm o risco de ser contaminadas pelo utilitário e pelo irracional. Mas quem nada arrisca, nada realiza.

3. Poderíamos deter-nos a uma definição suscetível de obter largo consenso entre pesquisadores que trabalham juntos em cursos de pós-graduação de educação, e de reforçar sua identidade comum. Tal defi- 
nição, aliás, acarreta conseqüências concretas, modos de organização e objetivos a serem alcançados.

Algumas pessoas, entre as quais me incluo, se perguntam se não se pode ir além da definição anterior, ir além de um simples espaço de circulação e mestiçagem, e construir uma disciplina que tivesse uma especificidade mais forte, com seus próprios conceitos e, eventualmente, métodos específicos de pesquisa. A questão fica aberta, eu não tenho resposta para ela. Mas pertenço ao grupo dos que têm vontade de reanimar nessa aposta, nesse desafio de uma especificidade das ciências da educação, e que inscreveram essa aposta em suas pesquisas.

Para refletir sobre isso, acredito que seja necessário começar por um inventário dos tipos de discursos existentes sobre educação. Com efeito, jamais uma ciência surgiu em um espaço vazio; uma ciência sempre se constrói conquistando um espaço no qual já havia um outro tipo de discurso (por exemplo, a sociologia ocupa um espaço em que antes havia discursos filosóficos, psicológicos e políticos).

\section{A área da educação: um espaço saturado de discursos diversos e múltiplos}

Podemos identificar ao menos sete tipos de discurso sobre a educação, que vou apresentar a seguir, rapidamente é claro, reunindo alguns entre eles.

1. Há discursos, de diferentes tipos, que negam o interesse ou a legitimidade de um discurso científico específico sobre a educação.

A. $O$ discurso espontâneo. Cada um tem uma experiência de educação, a sua ou a de seus filhos, e "sabe", ou acha que sabe, alguma coisa. Mas não se pode confundir ter uma opinião (dizer o que acreditamos, a partir de uma experiência pessoal) e produzir um saber (um discurso no qual a significação das palavras é controlada, no qual levamos em conta diversas formas de colocar o problema, vários pontos de vista, no qual nos apoiamos em provas que podem ser verificadas por qualquer um). Quem deseja fazer pesquisa em educação deve sair da esfera da opinião e entrar no campo do conhecimento.
Isso nem sempre é fácil... Quem orienta pesquisas de mestrado ou doutorado sabe que com freqüência os alunos desenvolvem uma pesquisa para "mostrar que...". Ou seja, mostrar coisas que eles já sabem de antemão... Pessoalmente, eu digo: Bem, vamos esquecer tudo aquilo que é inútil. Vamos esquecer a justificativa, uma vez que a justificativa de uma pesquisa é sempre a construção do conhecimento; vamos esquecer os objetivos, porque o objetivo de uma pesquisa é sempre entender o que não sabemos. Não quero as hipóteses, sobretudo, porque com suas hipóteses vocês já me dão os resultados de suas pesquisas, antes mesmo de começá-las. O que quero são duas coisas. Em primeiro lugar, o que vocês querem saber e que ninguém ainda sabe, inclusive eu? Porque se alguém já tem a resposta, não vale a pena fazer uma pesquisa. Quando sabemos aquilo que queremos conhecer, temos a base de um projeto de pesquisa. Pelo menos um ponto de partida, pois, na realidade, são necessários cerca de seis meses de trabalho sobre uma dada problemática para se definir uma questão de pesquisa. A segunda questão que coloco para os alunos que me apresentam um projeto de pesquisa é: como, concretamente, vocês farão isso?

Tudo isso pode ser escrito em uma página e meia. Não são necessárias vinte páginas, cheias de termos complicados e técnicos. Mas há de ser uma boa página e meia. Caso contrário, quando não sabemos escrever uma boa página e meia, somos obrigados a escrever vinte longas páginas... É dessa forma que funciona, tanto na França como no Brasil, e é preciso refletir sobre isso, porque esse momento de entrada na pesquisa é importante.

Um discurso científico sobre a educação não deve ser um discurso de opinião; ele não é científico se não controla seus conceitos e não se apóia em dados. A pesquisa em educação (ou sobre a educação) produz um saber, rigoroso como o é todo saber científico. Podemos sustentar, e eu particularmente o faço, que há diferentes formas de rigor. Essa idéia parece-me importante para a convivência, o trabalho conjunto, debates em um departamento de ciências da educação ou em uma pós-graduação em educação, em que é ne- 
cessário aceitar a diversidade como riqueza, incluindo-se aí a diversidade epistemológica e metodológica. Mas, após afirmar isso, é preciso que cada forma de rigor obedeça a regras e deva ser controlada por uma comunidade científica. Não somos obrigados a fazer pesquisa com qui quadrados, nem a fazer pesquisaação. Mas, se optamos por fazer a primeira, há normas estatísticas a respeitar. E, se optamos por fazer a outra, também haverá regras a respeitar, o que não consiste (como se supõe com frequiência) em agir e dizer que fazemos pesquisa porque refletimos e escrevemos sobre a ação que fazemos. Existem normas de produção científica. Elas são diversas em relação a alguns pontos, por vezes são até conflitantes, mas essas normas existem. Se não há regras, ou se não há uma comunidade para controlá-las, não há mais pesquisa, há uma conversa de botequim sobre a educação.

B. O discurso do "prático", que acredita saber porque tem uma prática. Ele opõe sua prática às teorias, com o argumento de que ele pode apresentar resultados enquanto o teórico só pode falar. É preciso sair dessa pseudo-oposição entre teoria e prática, e da idéia, a meu ver falsa, de um debate "entre a teoria e a prática”. Na verdade, aquilo que o prático opõe à teoria, não é, como ele acredita, sua prática, e sim seu discurso sobre sua prática. Ora, esse discurso utiliza conceitos o mais das vezes não controlados, e freqüentemente enraizados em uma teoria sem que ele o saiba. Por exemplo, a noção de carências. O prático diz que "vê" carências, ou deficiências, em sua classe, o que, por definição, é impossível, pois a "carência" é uma falta, uma ausência, um não-ser que não podemos "ver", mas somente identificar por uma comparação, o que pressupõe pensamento, uma interpretação do mundo. No que se considera confronto entre teoria e prática, há, na verdade, dois discursos que se confrontam.

Podemos interpelar o discurso do prático do ponto de vista de seus conceitos. E podemos interpelar o discurso do teórico do ponto de vista de seus dados, e da maior ou menor concordância entre esses dados e as situações reais nas quais os professores e profissionais trabalham. O prático pode sempre contestar os dados do pesquisador, dizendo que eles não têm qualquer relação com as condições nas quais ele trabalha, as condições nas quais trabalha um professor "normal". O pesquisador deve prestar atenção, talvez mais do que já faz, ao professor "normal". Se queremos mudar a educação no Brasil, é preciso desvencilhar-se dessa idéia, bem estranha quando pensamos sobre ela, de que para ser um bom profissional na área da educação e do ensino é necessário ter qualidades que são, na verdade, as de um santo ou de um militante. A situação "normal" - se podemos dizer dessa forma - do professor brasileiro é trabalhar em uma escola pela manhã e em outra à tarde, receber salários muito baixos e, com frequiência, mesmo havendo exceções, ter feito o vestibular para pedagogia porque era o mais fácil em determinada universidade. É essa a condição real do professor no Brasil, e, se queremos mudar a educação no Brasil, é preciso sempre pensar nesse profissional real, e não no professor santo ou militante. Conseqüentemente, o pesquisador deve controlar com bastante cuidado os dados que utiliza, e sua relevância em relação às condições de trabalho do docente real.

É preciso ter a coragem de dizer que a prática não é um argumento, e sim um elemento do debate que deve, ele próprio, ser analisado. É preciso também ter a coragem de dizer que a recusa do pesquisador ou do professor universitário de confrontar as teorias que ele ensina com as situações e práticas do professor ou do formador levanta suspeitas, sérias, sobre o valor de suas teorias, incluindo-se aí a questão do valor do ponto de vista da verdade. É óbvio que não é possível dar "receitas", isto é, modos de fazer que funcionam de imediato, que só precisam ser aplicados. A prática é sempre contextualizada, e uma receita nunca funciona. Entretanto, podemos e devemos definir técnicas a partir dos conhecimentos que a pesquisa produz e que ensinamos. Ou seja, modos de fazer, procedimentos, cujos fundamentos e limites de validade foram explicitados. Devemos responder à questão “como fazer?" explicando que, munidos dessas técnicas, cada professor deverá reinventar sua prática no contexto em que atua. 
C. O discurso dos "antipedagogos", que teve um certo sucesso na Europa, e, às vezes, mas isso está mudando, o discurso dos didatas de disciplinas, às vezes também o de alguns filósofos. Podemos resumi-los, de forma um pouco sumária, com o seguinte argumento: todo ser humano é dotado de razão, e a educação é um encontro entre a razão humana e os conhecimentos. O único problema a ser resolvido é permitir que cada um encontre o conhecimento. Não há "problema pedagógico" nenhum. Pelo contrário, a pedagogia perverte a juventude, ela inventa artifícios para aprender no prazer, ela afasta a juventude do esforço e, portanto, ela a afasta do verdadeiro saber, pois não alcançamos o saber sem esforço, sem trabalho crítico.

Essa objeção apresenta-se de forma democrática (a razão é universal, cada um tem o direito ao conhecimento), mas, na verdade, produz efeitos bastante elitistas: na realidade, se não acompanhamos, de uma forma ou de outra, o acesso dos jovens ao conhecimento, a ele chegam aqueles que, de fato, recebem apoio na família ou nas escolas particulares. O erro dos que defendem essa posição é acreditar que a simples apresentação do conhecimento põe a inteligência em movimento. Ao passo que a questão fundamental a ser resolvida por aquele que ensina é saber como provocar uma mobilização intelectual daquele que aprende. No direito, a Razão é universal, mas, na verdade, ela não é mobilizada espontaneamente, imediatamente e da mesma forma por cada indivíduo que encontra uma oportunidade de aprender. O problema pedagógico fundamental está aí: obter, de uma forma ou de outra, uma mobilização intelectual do aluno.

Da mesma maneira, durante muito tempo a didática (francófona e anglófona) supôs estar já produzido o Eu epistêmico. Ora, na realidade, se supõe-se o Eu epistêmico já produzido, não há mais dificuldade para ensinar. O problema fundamental é, precisamente, passar do Eu empírico ao Eu epistêmico, ou seja, do indivíduo preso no movimento da vida cotidiana ao indivíduo intelectualmente mobilizado, atento ao saber. Há dois ou três anos, didatas franceses e canadenses, principalmente os que trabalham com matemática e ciências, engajaram-se nessa reflexão, utilizando a noção de relação com o saber. Essa evolução contribui, e contribuirá, para reduzir as distâncias entre pesquisadores em educação e pesquisadores em didáticas das disciplinas. Mas é um movimento recente, por isso não sei se já produziu efeitos no Brasil.

2. Há um discurso que, ao contrário, trata especificamente da educação e pode ser confundido com o discurso das ciências da educação: é o discurso pedagógico.

Podemos, é claro, designar coisas diferentes com a palavra "pedagogia", quando tratamos daquilo que a pedagogia deveria ser e poderia ser, daquilo que consideramos sua essência. Mas quando consideramos aquilo que ela foi historicamente, o que são as pedagogias que surgem, com esse nome, em tal ou qual época, nos damos conta de que elas têm uma característica fundamental: elas unem diretamente os fins e as práticas (ou técnicas). Há uma pedagogia tradicional (que não tem nada a ver com aquilo que recebe essa denominação e que é menosprezado no Brasil...), uma pedagogia Montessori, uma pedagogia Freinet, uma pedagogia Paulo Freire etc. Cada uma é um conjunto de fins ligados a uma concepção filosófica e muitas vezes política, da infância e do homem, e traduzidos em práticas específicas. A pedagogia não é fundamentalmente um campo de saberes, é um campo de axiologia prática, poderíamos dizer, um campo de valores com os meios de colocá-los em ação, ou um campo de práticas ordenadas para determinados fins. Nesse sentido, muito mais que conhecimentos, a pedagogia produz descrições, relatórios de experiências, manifestos. Porque tem sempre um lado prático e militante, ela é objeto de experimentações, de debates, de pesquisa-ação, e produz mais convicções, instrumentos e inovações do que conhecimentos demonstrados. Afirmar isso não significa depreciar a pedagogia; é constatar que ela está centrada nas práticas e nos fins, e no elo entre os dois, e não nos saberes. O que não quer dizer que ela não sabe nada; ela pode veicular saberes obscuros, implícitos, ligados às práticas, interessantes para a pesquisa. Assim, as pedagogias "novas" foram construtivistas mais de meio século antes do surgimento do termo "construtivista". 
3. Há os discursos que podemos denominar os discursos "dos outros". São aqueles discursos sobre a educação produzidos por disciplinas de ciências humanas, principalmente a psicologia e a sociologia. Esses discursos dominaram por bastante tempo a área da educação, e ainda hoje ocupam nela um espaço significativo.

Por exemplo, o discurso "construtivista" é um discurso que se desenvolveu no campo da educação, mas que surgiu fora dele. Seus dois teóricos são Piaget e Bachelard. Piaget, que podemos considerar um psicólogo, mas que é sobretudo biólogo e lógico (são os processos de assimilação e de acomodação, pensados com base num modelo biológico, que constroem pouco a pouco as estruturas lógicas da inteligência). Bachelard, que é um historiador das ciências e um epistemólogo que estudou a formação do pensamento científico. Nem Piaget nem Bachelard são pesquisadores "em educação"; seus projetos científicos são outros. E Vygotsky era inicialmente um teórico da literatura... Em outras palavras, o discurso hoje dominante no campo da aprendizagem não vem da pesquisa em educação, mas de outros campos de pesquisa.

Poderíamos também considerar o discurso da sociologia da reprodução, que explicou a duas gerações de professores que a escola contribui para a reprodução, de geração em geração, das desigualdades sociais. Isso significa (indo um pouco rápido, mas foi assim que o discurso foi interpretado) que ele explicou que os professores não servem para nada, ou servem apenas para pouca coisa, nada podem, ou podem pouca coisa... Os professores gostaram bastante desse discurso, por razões que não tenho tempo de analisar aqui, mas que, no fundo, têm a ver com o fato de que, se os alunos não aprendem, a culpa não é dos professores, é da sociedade. O interessante, aliás, é que essa idéia não é equivocada: quando o professor e o aluno fracassam, é também uma falha da sociedade. Mas não é somente uma falha da sociedade...

O discurso "dos outros" é importante, é preciso levá-lo em conta. Mas é preciso também saber o que faz a pesquisa educacional para não apenas acompanhar esse discurso dos outros.
4. Enfim, para atermo-nos aos grandes tipos de discurso, há os discursos políticos sobre educação.

Eles são de vários tipos. Vou abordar aqui os dois tipos principais.

A. Há um discurso militante, que com frequiência se apóia na sociologia da reprodução e, atualmente, na crítica da globalização neoliberal. Ele parte de fundamentos exatos: é certo que as crianças são socialmente desiguais no que se refere à escola, é certo que o neoliberalismo considera a educação como uma mercadoria, e não como um direito. Mas esse discurso político tende a ignorar as diferentes ordens e escalas dos fenômenos. Ele tem a tendência de utilizar explicações amplas, "macros", para dar conta de todas as ordens de fenômenos, inclusive os fenômenos “micros”. Então, não há mais pesquisa possível, pois a resposta já está dada.

Isso ocorre, por exemplo, com a idéia de que, se as crianças são violentas na escola, é em razão da pobreza. É difícil negar que a violência do bairro tenha efeitos sobre a escola. Mas ignora o fato de que existem escolas pouco violentas em bairros violentos e o fato mais perturbador, de que entre as crianças pobres só uma pequena minoria é violenta. Em outras palavras, não é suficiente considerar a pobreza para dar conta da violência dentro da escola. É preciso que haja pesquisa com dados, e os discursos políticos préconstruídos não são suficientes, inclusive quando são politicamente certos.

Há aí um desafio que me parece particularmente importante para a pesquisa em educação no Brasil. Trata-se, ao mesmo tempo, de integrar à pesquisa o fato de que a educação tem uma dimensão política, e não pode deixar de tê-la, e de se recusar a reconhecer como pesquisa textos em que a análise precisa de dados precisos é substituída por discursos políticos muito genéricos. É inegável que a globalização neoliberal faz surtir efeitos sobre a situação da escola no Brasil. Da mesma forma, é inegável que as dificuldades que os alunos brasileiros encontram para aprender a ler não são os efeitos diretos da política do Banco Mundial e do Fundo Monetário Internacional, e estão ligadas às práticas dos profes- 
sores. Articular as análises "macro" e "micro" é um desafio fundamental da pesquisa em educação, no mundo inteiro. Explicar diretamente o "micro" pelo "macro", ou o "macro" pelo "micro", é um erro epistemológico e metodológico, que deve ser tratado como tal, quaisquer que sejam as boas intenções políticas desse erro.

B. Há, igualmente, um discurso gerado por instituições internacionais e que se difunde pouco a pouco nos círculos dirigentes, em seguida junto aos jornalistas e, por meio deles, na opinião pública. No mundo, a principal agência de produção de discurso político sobre a educação é, há 50 anos, a Organização de Cooperação e Desenvolvimento Econômico (OCDE), e, em seu rastro, o Banco Mundial. A OCDE ocupa-se da educação desde o final da década de 1950 (mais precisamente, depois do lançamento do Sputnik russo). Foi dela que surgiu a reforma da matemática moderna. Foi dela que, ao longo dos anos de 1980, surgiu o discurso sobre a "qualidade" da educação. Foi dela que se originou a proeminência atual da questão da avaliação. Ela construiu e divulgou, há mais de vinte anos, uma ideologia que se tornou dominante entre os políticos, em que as palavras-chave são "qualidade", "eficácia", "avaliação". Trata-se de um discurso do domínio e da transparência: saber tudo, controlar tudo, prever tudo, como o Panóptico de Bentham e de Michel Foucault. Trata-se também, com frequiência, de um discurso que acredita que a inovação é, em si, um progresso.

Esse discurso não é automaticamente neoliberal. É difícil sustentar que se possa ensinar sem prestar atenção à qualidade e à eficácia desse ensino. Podemos ser de esquerda e defender a idéia de uma "qualidade social" da educação, como se diz no Brasil. Mas, se não acompanharmos de perto esse discurso, ele torna-se rapidamente neoliberal; basta supor, como faz o Banco Mundial, que só a privatização do ensino e a constituição de um mercado da educação podem assegurar a qualidade e a eficácia da educação. Esse discurso é perigoso, como podemos verificar hoje em dia no Brasil. Aqui houve uma boa escola pública, que não mais existe há muito tempo. Depois que essa escola foi deixada de lado pelos poderes públicos, sem os recursos e o apoio de que necessitava, o nível de formação dos jovens brasileiros ficou melhor, graças ao mercado? Não. O nível de alguns melhorou, nas escolas privadas (não em todas, aliás), e o nível de outros, da maioria, foi abandonado. O discurso neoliberal de certas organizações internacionais é ainda mais perigoso para o pesquisador quando vem acompanhado por instrumentos de poder: a difusão de temas que, repetidos, se impõem com uma pseudo-evidência, a encomenda de pesquisas por instituições públicas, as verbas e bolsas para equipes de pesquisadores.

Essa é a situação com que um jovem pesquisador se depara quando se engaja em pesquisas em educação. O campo da educação está saturado de discursos já instalados, já prontos. Qualquer que seja a questão, já há uma resposta, prática ou política, já existem discursos teóricos, poderes intelectuais constituídos, panelinhas teóricas nas quais a defesa de conceitos mais ou menos se confunde com a conquista de postos e de poderes. Quando um campo está tão saturado de respostas, é difícil levantar questões de maneira nova; portanto, é difícil fazer pesquisa.

Em contrapartida, há uma pressão, difusa, implícita, exercida sobre a escolha dos objetos de pesquisa. Existe o que chamo de objetos sociomidiáticos. São aqueles objetos que a opinião pública e os políticos, e na sua esteira os jornalistas, questionam, sobre os quais a atenção se volta sem cessar, como se fossem questões importantes, que têm de ser resolvidas (e aí, o que faz a pesquisa?). Evidentemente, é grande a tentação de tomá-los como objetos de estudo. Ainda mais porque são aqueles para os quais se encontra verba para pesquisa. Trata-se de objetos de discurso, socialmente relevantes, mas que não são, enquanto tais, objetos de pesquisa. Hoje em dia, os principais são: o fracasso escolar, a violência na escola, a cidadania, a parceria educativa, a qualidade da educação, a avaliação, e ainda, sem nunca sair de moda, a formação de professores. Seria interessante fazer uma análise de conteúdo, especialmente a partir dos títulos dos projetos de pesquisa educacional fi- 
nanciados pelos órgãos científicos e universitários brasileiros, o Conselho Nacional de Desenvolvimento Científico e Tecnológico (CNPq) sobretudo. Isso permitiria identificar os temas que são apoiados, valorizados, considerados prioritários numa dada época, e saber se trata-se de objetos científicos ou sociomidiáticos. Podemos fazer uma pesquisa partindo de temas sociomidiáticos que não são apenas simples efeitos da moda, mas que remetem a problemas sociais fundamentais. Porém isso pressupõe que se defina, a cada momento, um objeto de pesquisa, pois esses temas não são, e não podem ser, enquanto tais, objetos de pesquisa.

O objeto da pesquisa assim definido pode ser pensado em relação a uma disciplina: filosofia, sociologia, psicologia, história etc., da educação, ou didática desta ou daquela matéria. Essas pesquisas, evidentemente, têm seu lugar em uma pós-graduação em educação. Também podem ser pesquisas de um tipo mais pedagógico, que investigam os vínculos entre fins e práticas, mais do que produzem conhecimento. Podemos ir além, e ter a ambição de construir uma disciplina - educação ou ciências da educação - que tenha uma especificidade e conceitos próprios? Não se trata de construir a partir do nada. Hoje já existem muitas pesquisas em educação que não sabemos muito bem onde enquadrar. Mas elas continuam esparsas, justapostas, em vez de articuladas. Não sabemos bem se se trata de objetos estranhos, misturados, fora dos padrões, ou produtos de uma disciplina que ainda não existe...

\section{Em direção a uma disciplina específica, denominada educação?}

O que foi dito anteriormente pretende possuir o estatuto da análise, e baseia-se em dados. O que segue não pretende mais isso. Trata-se de convicções, apostas, desafios, que repousam sobre posturas epistemológicas. Mas, precisamente, é com apostas epistemológicas que se constrói uma disciplina. Proponho aqui algumas delas, para um debate que permanece aberto.

\section{Quais especificidades?}

Em primeiro lugar, convém levar em consideração o que há de mais específico na educação. De minha parte, proponho definir essa especificidade argumentando que, de um lado, a educação é um triplo processo; e, de outro, que educar, educar-se, aprender, ensinar, operam sempre numa tripla articulação.

A educação é um triplo processo de humanização, socialização e entrada numa cultura, singularização-subjetivação. Educa-se um ser humano, o membro de uma sociedade e de uma cultura, um sujeito singular. Podemos prestar mais atenção a uma dimensão do que a outra, mas, na realidade do processo educacional, as três permanecem indissociáveis. Se queremos educar um ser humano, não podemos deixar de educar, ao mesmo tempo, um membro de uma sociedade e de uma cultura e um sujeito singular. E, partindo da socialização ou da singularização, podemos produzir enunciados análogos.

Em contrapartida, o ato de ensino-aprendizagem dá-se em uma tripla articulação.

É o jovem que se educa, que aprende. Vamos considerar a vertente da aprendizagem, mas seria a mesma coisa com a vertente da educação. Se o jovem não se mobiliza intelectualmente, ele não aprende. $\mathrm{O}$ que quer que o professor faça, ele não pode aprender no lugar do aluno. Ou, se preferirmos: só o aluno pode fazer aquilo que produz conhecimento, e o professor só pode fazer alguma coisa para que o aluno o faça. Evidentemente, sempre com um coeficiente de incerteza. Nesse sentido, o trabalho do professor não é ensinar, é fazer algo para que o aluno aprenda. Com freqüência, esse "algo" consistirá em ensinar; outras vezes, pode tomar uma outra forma.

Entretanto, esses dois termos (educando, educador) articulam-se com um terceiro: uma instituição (a escola, mas poderia também ser a família ou outra instituição). Trata-se de uma instituição social, submetida a políticas. Em outras palavras, preservando a vertente da aprendizagem escolar, a atividade do aluno e a do professor operam em um quadro institucional que define as condições materiais, financeiras, 
burocráticas etc. Essa instituição não pode produzir o conhecimento no aluno, contrariamente às visões de transparência e de controle total daqueles que dão tanta importância à avaliação que ela termina por prevalecer sobre a própria aprendizagem. A instituição pode apenas fazer algo que talvez modifique aquilo que o professor e o aluno fazem. Existe aí uma articulação fundamental entre três ações de "fazer", na qual o poder político está do lado da instituição e o poder intelectual do lado do professor, mas na qual aquilo que produz, em última instância, o sucesso ou o fracasso do empreendimento está do lado do aluno.

Eis aí uma das chaves para compreender a condição do professor: ele deve fazer alguma coisa, e ele será cobrado por aquilo que tiver feito, mas ele não pode produzir diretamente o resultado de sua ação. $\mathrm{O}$ que vai produzir ou não o conhecimento é a atividade intelectual do aluno, e este tem a capacidade de bloquear todo o processo.

Eis aí também uma chave para compreender as possibilidades e os limites das políticas educativas. Nenhuma reforma política, por si só, resolve um problema educacional. Acreditar nisso é pensar como o Banco Mundial e a OCDE: vou mandar fazer e avaliar, para verificar se eles fazem. Isso nunca funciona. Quem empreende uma reforma política no campo da educação deve perguntar-se: "Como é que isso que estou fazendo vai modificar as práticas dos professores e as dos alunos?". Porque, se aquilo que se faz nada muda nessas práticas, então não terá nenhum resultado. Seria interessante voltar a analisar, a partir dessa perspectiva, a reforma que substituiu a escola seriada pela escola ciclada. A escola em ciclos é bem melhor que a escola seriada, mas com uma condição: que sejam implementadas práticas dos professores e dos alunos que correspondam ao projeto da escola em ciclos. Porque, se as práticas continuarem a ser as da escola seriada, a escola em ciclos não funcionará, e poderá até mesmo ser pior.

Toda ciência recorta seu objeto na complexidade do real. A psicologia pode, é seu direito, decidir interessar-se pela educação como processo de subjetivação; a sociologia, como processo de socialização; a filosofia, como processo de humanização. Se uma disciplina específica educação chegar a existir, creio que será tomando como objeto o triplo processo, instalando-se no coração do processo, recusando-se a deixar de fora seja a humanização, seja a socialização, seja a singularização.

Da mesma forma, uma pesquisa pode interessarse seja pela atividade de aprendizagem do aluno (as didáticas), seja pela atividade do professor e por sua formação, seja pelas políticas da educação. Mas se uma disciplina específica educação chegar a existir, creio que será levando em conta as articulações entre as três formas de atividade: a do aluno, a do professor e a das políticas.

Isso acarreta, no mínimo, duas conseqüências.

Em primeiro lugar, isso significa dizer que uma disciplina específica educação deve estar muito atenta às contradições, às tensões, às defasagens, à heterogeneidade das lógicas. A educação é um triplo processo, que opera em uma tripla articulação, o que, naturalmente, engendra tensões e modos de funcionamento heterogêneos. De minha parte, em minhas pesquisas, trabalhei muito as lógicas heterogêneas; penso ter sido capaz de mostrar que o sentido que os alunos das classes populares dão ao fato de irem à escola e aprender é muito diferente do sentido que isso faz para os professores. Mas esse é apenas um exemplo; há muitos outros.

A segunda consequiência é que é necessário, ao mesmo tempo, distinguir cuidadosamente os níveis de realidade analisados e identificar o modo como um nível opera nos demais. Existe, ali também, acredito, uma especificidade de uma pesquisa em educação. O que acontece numa sala de aula decorre de um certo nível de realidade, do qual não podemos dar conta com conceitos como "reprodução" ou "globalização", que têm a ver com outro nível da realidade. Mas não há como ignorar o fato de que a desigualdade social e o neoliberalismo igualmente produzem efeitos na sala de aula. Que efeitos, produzidos de que maneira, através de quais mediações? De modo inverso, a acumulação de estratégias individuais produz efeitos coletivos. Quais, como? Es- 
tas são, acredito, questões específicas, para uma disciplina específica.

\section{Como fazer, concretamente?}

Depois de definidas as particularidades de uma disciplina educação, resta uma questão: como fazer, concretamente, para, além das pesquisas que levam em consideração essas especificidades, construir uma disciplina organizada, passível de ser identificada? A questão não é trivial, e ela também permanece aberta. Na minha opinião, é preciso solucionar o problema dos pontos de partida e da memória. Vou explicar.

Como avançam as ciências "duras" (física, química, biologia...)? Elas avançam a partir de seus pontos de chegada: quando constroem um objeto novo, elas o abrem, o questionam para saber do que ele é feito. Quando temos a molécula, vamos abri-la para encontrar o átomo, em seguida abrimos este último, etc. Quando temos um gene, o abrimos e trabalhamos o DNA. Essas ciências trabalham a partir de seu ponto de chegada, por isso são consideradas ciências cumulativas. Mesmo quando esse trabalho sobre os pontos de chegada leva à redefinição dos pontos de partida, a perspectiva anterior permanece integrada como um caso particular da nova perspectiva (o universo de Newton é um caso particular do universo de Einstein).

As ciências do homem e da sociedade não avançam segundo o mesmo modelo. Elas progridem a partir de seus pontos de partida. Quando há avanço nessas ciências é porque foi proposta uma outra forma de começar (e porque se prova que ela produz resultados). Foi assim que fizeram Durkheim, Freud, Marx, Pavlov, Braudel, Lévi-Strauss, Bourdieu, Garfinkel, Goffman, Lacan, Piaget, Vygotsky, enfim, todos os grandes nomes das história das ciências sociais e do homem.

Por isso não há acumulação nessas ciências. Em compensação, elas têm uma memória. Durkheim não deixou de ser interessante e de nos ensinar coisas, ainda que, hoje em dia, não faça tanto sentido se dizer um "durkheimiano".

Se aceitamos essa análise, a conseqüência é que uma disciplina educação não surgirá como específica, para além de um grande número de pesquisas esparsas, a não ser que ela venha a definir alguns pontos de partida que a especifiquem. Levando em conta as análises precedentes, esses pontos de partida devem expressar o cuidado com o triplo processo ou a tripla articulação que esbocei anteriormente. Acredito que a noção de relação com o saber é um desses pontos de partida, e que seu sucesso reside no fato de que ela fornece um ponto de apoio para trabalhar aquilo que existe de específico na educação. Mas há, sem dúvida, outros pontos de partida, ainda a serem identificados.

Se concordamos com a análise sobre o modo como as ciências humanas e sociais são construídas e vivem, é igualmente necessário trabalhar a questão da memória. As ciências da educação na França, a pesquisa educacional no Brasil, carecem de memória. A principal consequiência disso é que refazemos continuamente as mesmas teses, as mesmas dissertações, sem sabermos o que foi produzido anteriormente. Fazemos uma tese que já foi feita há dez anos, no mesmo país ou no exterior, e até mesmo, às vezes, uma tese que foi defendida uma semana antes, em outra universidade, sem que tivéssemos conhecimento disso. Também nos esquecemos dos debates que aconteceram em décadas anteriores, em proveito dos autores "da moda". Nossa disciplina não tem uma memória suficiente, e isso freia o progresso da pesquisa em educação. De minha parte, defendo, há dez anos, a idéia de definir uma frente da pesquisa, que seria também uma memória. $\mathrm{O}$ que sabemos que foi estabelecido? Sobre o que discutimos hoje em dia, o que questionamos, e quais as posições assumidas no debate? Que pesquisas já foram realizadas sobre os temas que estão na moda (os objetos sociomidiáticos), a partir de quais questões, com que dados, e quais os resultados? Quais foram as dissertações de mestrado e as teses de doutorado defendidas nos últimos anos, e que resultados foram estabelecidos? Que pesquisas estão atualmente em andamento, sobre que temas, onde? Para que progrida a pesquisa em educação no Brasil, para que ela se organize, ganhe visibilidade, para que se definam, pouco a pouco, "pontos de partida" e pontos de apoio, existe um trabalho a ser feito. Quando um jovem pesquisador chega a um de- 
partamento de genética, ele não vai dizer "Vou estudar a reprodução das moscas"; e, se o diz, responderemos a ele que isso foi feito há mais de um século, por Mendel. Mas ocorre com bastante frequiência na França, no Brasil e provavelmente em outros países, um jovem pesquisador anunciar que vai resolver o problema do fracasso escolar em seu mestrado...

Tornou-se urgente constituir um arquivo coletivo da pesquisa em educação e definir uma ou várias frentes da pesquisa. Acredito que, no Brasil, esse é um trabalho que deveria ser assumido pela ANPEd, talvez em parceria com o CNPq e com outras instituições. A ANPEd tem hoje 28 anos. É uma idade em que ainda temos a audácia e as ambições da juventude, aliadas a uma certa maturidade própria da idade adulta. É, portanto, uma boa idade para lançar-se, de forma racional, em um empreendimento um tanto ou quanto ousado.

\section{Referências bibliográficas}

CHARLOT, Bernard. Les sciences de l'éducation; un enjeu, un défi. Paris: ESF Editora, 1995.

BERNARD CHARLOT é professor emérito em ciências da educação da Universidade Paris 8, na França, e consultor da Organização da Nações Unidas para a Educação, a Ciência e a Cultura (UNESCO) no Brasil. Publicou onze livros e organizou outros cinco. O último, Relação com o saber, formação dos professores e globalização: questões para a educação hoje, foi publicado diretamente no Brasil, pela editora Artes Médicas, em 2005.

Realizou recentemente, para o governo de Sergipe, uma pesquisa intitulada "Juventudes sergipanas", financiada pela UNESCO. Email:bernard.charlot@terra.com.br

Recebido em outubro de 2005 Aprovado em dezembro de 2005 


\section{Resumos/Abstracts/Resumens}

\section{Bernard Charlot}

A pesquisa educacional entre conhecimentos, políticas e práticas: especificidades e desafios de uma área de saber

Será que pode ser definida e construída uma disciplina específica, chamada educação ou ciências da educação? O autor apresenta três respostas possíveis. Primeira: os departamentos de educação não passam de um agrupamento administrativo de matérias interessadas pela educação. Segunda: esse próprio agrupamento gera uma especificidade das pesquisas, entre conhecimentos, políticas e práticas. A terceira resposta consiste em apostar em uma disciplina específica. Nessa última perspectiva, são analisados sete tipos de discursos atuais sobre educação: espontâneo, dos práticos, dos antipedagogos, da pedagogia, das ciências humanas, dos militantes e das instituições internacionais. Nesse campo já saturado de discursos, qual lugar para um discurso científico específico? Para responder a essa pergunta, o autor apresenta algumas propostas teóricas e práticas.

Palavras-chave: educação; ciências da educação; pesquisa em educação

Educational research amid

knowledge, policies and practice: specificity and challenges of an area of knowledge

Is it possible to define and construct a specific discipline called education or science of education? The author presents three possible replies. First, departments of education are no more than mere administrative groupings of subjects interested in education.

Second, this very grouping generates a specificity of research amid knowledge, policy and practice. The third reply consists of betting on a specific discipline. In this last perspective, seven types of current discourse on education are analysed: spontaneous, practical, antipedagogic, pedagogic, human science, militant and of international institutions. In this field already saturated with discourses what space is there for a specific scientific discourse? In order to respond to this question, the author presents some theoretical and practical proposals.

Key-words: education; science of education; educational research

La pesquisa educacional entre conocimientos, políticas y prácticas: especificaciones y desafíos de una área del saber

¿Será que puede ser definida y construida una disciplina específica, llamada

educación o ciencias de la educación?

El autor presenta tres respuestas

posibles: Primera: los departamentos

de educación no pasan de un

agrupamiento administrativo de materias interesadas por la educación. Segunda: ese propio agrupamiento genera una especificación de las pesquisas, entre conocimientos, políticas y prácticas. La tercera respuesta consiste en apostar en un método específico. En esta última perspectiva, son analizados siete tipos de discursos actuales sobre educación: espontáneo, los prácticos, los antipedagógicos, de pedagogía, de ciencias humanas, de militantes y de instituciones internacionales. En este campo ya saturado de discursos, ¿cuál es el lugar para un discurso científico específico?. Para responder a esta pregunta, el autor presenta algunas propuestas teóricas y prácticas.

Palabras claves: educación; ciencias de la educación; pesquisa en educación

Nelson Pretto e Cláudio da Costa Pinto

Tecnologias e novas educações

$\mathrm{O}$ artigo analisa a sociedade contemporânea, a partir das transformações do mundo científico, tecnológico, cultural, social e educacional, com o objetivo de fazer uma crítica a este. Considera importante a re-aproximação entre a cultura e a educação, entendidas no plural, e destas com as tecnologias da informação e comunicação (TIC). Aborda os avanços das TIC e os movimentos de concentração na propriedade dos meios de comunicação de massa, faz a sua crítica, e apresenta as propostas em andamento na Faculdade de Educação da UFBA para a formação de professores, conside- 